\title{
Establishing a New Role for Antidumping Policy: Protection of an Unestablished Industry (Morocco-Hot-Rolled Steel (Turkey))
}

\author{
Meredith A. Crowley ${ }^{1 \star}$ and Federico Ortino ${ }^{2}$ \\ ${ }^{1}$ Faculty of Economics, University of Cambridge, UK and ${ }^{2}$ Department of Economic Law, King's College London, UK \\ *Corresponding author: Email: meredith.crowley@econ.cam.ac.uk, mc865@cam.ac.uk
}

(Received 16 February 2021; accepted 16 February 2021; first published online 1 April 2021)

\begin{abstract}
This article analyses economic and legal issues in the WTO dispute between Morocco and Turkey over hot-rolled steel. Over 2013-2014, the Moroccan government conducted an antidumping investigation against two Turkish steel producers. Morocco's investigation concluded that Turkish dumping was retarding the establishment of a new domestic industry; antidumping duties were imposed against both Turkish producers. Turkey filed a complaint at the WTO in 2016, asserting procedural and substantive violations. The Panel found that Morocco had acted inconsistently with a number of WTO obligations, including those regarding its injury investigation. Although Morocco initially appealed the Panel's decision, it withdrew its appeal after the antidumping duties expired in September 2019. This case is unusual and important in that it was the first antidumping case in which a country sought to use antidumping duties to protect a newly developing industry. The Panel may have missed an opportunity to explore the definition of an 'unestablished' industry for purposes of determining injury in an antidumping investigation.
\end{abstract}

Keywords: Anti-dumping; hot-rolled steel; WTO dispute; injury investigation; infant industry protection; unestablished industry

\section{Background}

In 2010, Mahgreb Steel, the sole producer of steel in Morocco, expanded its product offerings and began producing hot-rolled steel. ${ }^{1}$ This hot-rolled steel was used internally as an input into some of Mahgreb's other products and sold externally to arm's length customers in Morocco. By 2012, Mahgreb had captured $70 \%$ of the Moroccan market for hot-rolled steel, including its own self-purchases. ${ }^{2}$ Despite this high market share, there was concern that intense competition from two Turkish producers, Erdemir Group and Colakoglu, had led Mahgreb to incur losses on its sales to arm's length domestic customers. In January 2013, Morocco's Ministry of Industry, Commerce and New Technologies, Department of External Commerce initiated an antidumping investigation against Turkey.

Early on, the Moroccan Investigating Authority decided that, because Mahgreb had been operating as a hot-rolled steel producer for less than 36 months, ${ }^{3}$ the investigation into injury would focus exclusively on whether dumping by the Turkish producers had materially retarded the

\footnotetext{
${ }^{1}$ Panel Report, Morocco - Anti-Dumping Measures on Certain Hot-Rolled Steel from Turkey (Morocco-Hot-Rolled Steel (Turkey)), WT/DS513/R, footnote 223.

${ }^{2}$ Mahgreb Steel held $40 \%$ of the market for hot-rolled steel in Morocco if its own purchases were excluded. Panel Report, Morocco-Hot-Rolled Steel (Turkey), para. 7.167.

${ }^{3}$ Morocco's Minstere de l'industrie, du Commerce et des Nouvelle Technologies, Departement du Commerce Exterieur (MDCCE) reported that there were only 30 months of historical production data available when the case was investigated. Panel Report, Morocco-Hot-Rolled Steel (Turkey), para. 7.157.

(c) The Author(s), 2021. Published by Cambridge University Press. This is an Open Access article, distributed under the terms of the Creative Commons Attribution licence (http://creativecommons.org/licenses/by/4.0/), which permits unrestricted re-use, distribution, and reproduction in any medium, provided the original work is properly cited.
} 
development of a new industry in Morocco. The Investigating Authority proceeded to examine five empirical test criteria that it defined as providing a useful evidence base for this assessment.

On its surface, the decision to pursue the case as one of dumping inhibiting the development of a new industry might seem strange. Although Mahgreb had been producing hot-rolled steel for less than three years, the firm had been successfully operating since $1975 .{ }^{4}$ After Mahgreb was founded as a steel tube producer, it experienced two important expansions. In 2000, a large investment allowed it to expand cold-rolled steel production at its Tit Mellil complex. A second major expansion, which resulted in the hot-rolled steel production complex of Bleb Solb, began in 2007 and became the focus of the antidumping case.

The injury investigation broke new ground for antidumping; although the Agreement on Antidumping's definition of 'injury' includes 'material retardation of the establishment of ... an industry', to the best of our knowledge, this is the first case that came before the WTO regarding dumping and establishment of a new industry. This meant that the Moroccan Investigating Authority was, in some sense, working with a blank slate in terms of defining and evaluating clear and objective empirical criteria.

After definitive final antidumping duties were imposed against the two Turkish producers, the Turkish government brought its complaint to the WTO. Its objections ranged from procedural issues to concerns with the injury test criteria Morocco used and how these criteria were applied. Ultimately, while the Panel found for Morocco on a handful of issues, it sided with Turkey on most substantive points, finding Morocco's actions were inconsistent with its WTO obligations.

Morocco appealed the finding to the Appellate Body. However, the case backlog at the Appellate Body meant that Morocco's appeal could not be heard in a timely manner. In September 2019, the period of antidumping protection expired and antidumping duties against the Turkish producers terminated. Morocco withdrew its appeal, but noted that it still objected to many of the findings in the Panel Report.

\section{Summary of the Dispute at the WTO and Panel Decision}

In October 2016, Turkey requested consultations with Morocco regarding the definitive anti-dumping measures imposed by Morocco on imports of certain hot-rolled steel products from Turkey, claiming these measures were inconsistent with several provisions of the Anti-Dumping (AD) Agreement.

Upon a petition from Maghreb Steel, the only domestic producer of the like product, the Moroccan authority initiated a dumping investigation on 21 January 2013. Focusing on two Turkish producers, Erdemir Group and Colakoglu, Morocco first imposed provisional antidumping duties on certain hot-rolled steel from Turkey on 29 October 2013 and then published the final determination of dumping, injury, and causation on 12 August 2014.

Turkey's claims principally revolved around (a) certain failures in the investigation carried out by Morocco in violation of Articles 5.10, 6.5, 6.8, and 6.9 of the AD Agreement and (b) the determination of injury in violation of Articles 3.1 and 3.4 of the AD Agreement. Together with a request to reject all of Turkey's claims, Morocco also requested the Panel to rule that certain claims were outside the Panels terms of reference.

\subsection{Jurisdictional Objections}

With regard to the Morocco's jurisdictional objections, the Panel accepted in part Morocco's request and concluded that certain claims based on (i) footnote 9 to Article 3 ADA in respect

\footnotetext{
${ }^{4}$ History of Mahgreb Steel taken from the company webpage, www.maghrebsteel.ma/, accessed September-November 2020 .

${ }^{5}$ Footnote 9 of the ADA reads: 'Under this Agreement, the term "injury" shall, unless otherwise specified, be taken to mean material injury to a domestic industry, threat of material injury to a domestic industry or material retardation of the establishment of such an industry, and shall be interpreted in accordance with the provisions of this Article.'
} 
of the finding of 'establishment', (ii) Articles 6.5 and 6.5.1 ADA in respect of the confidential treatment of the domestic industry's break-even threshold, and (iii) Article 6.9 ADA in respect of the alleged failure to inform all interested parties of the domestic industry's break-even threshold, were outside the Panel's terms of reference.

Specifically, with regard to the footnote 9 claim, the Panel found that Turkey's panel request did not 'provide a brief summary of the legal basis of the complaint sufficient to present the problem clearly' as required by Article 6.2 of the DSU. With regard to the other two claims, the Panel found that they had not been included in the request for consultation and that they were not 'sufficiently closely and clearly connected with' the claim under Article 3.1 in the request for consultations. Moreover, the Panel rejected Turkey's argument that the same two claims 'evolved' from Turkey's injury claims as, during consultations, the (important) role of the break-even threshold in the injury determination became clear. The Panel did not find this assertion 'credible' as Turkey 'would likely have been aware of the break-even threshold's significance' and its confidential treatment by the Moroccan authorities since the issuance of the preliminary determination on 30 October 2013, in which the break-even threshold was redacted. ${ }^{6}$

On the other hand, the Panel rejected Morocco's jurisdictional request with regard to Turkey's claims under Articles 3.1 and 3.4 ADA. Morocco had argued that, in its request for consultations, Turkey had failed to provide an 'indication of the legal basis' of the claims under Articles 3.1 and 3.4 in respect to certain findings concerning injury. In finding that the claims fell under its terms of reference, the Panel emphasized that the DSU requires 'different levels of specificity for the identification of claims in the request for consultations and the panel request'. 'Referring to earlier Panel and Appellate Body reports, the Panel noted the following: "Neither "precise and exact identity" between the claims in the request for consultations and the panel request is required, nor should "too rigid a standard" of the identity be imposed.8 ${ }^{,}$Moreover, the Panel noted that the requirement in Article 4.4 DSU that a request for consultations contain 'an indication of the legal basis for the complaint' is a lesser requirement than that of Article 6.2 DSU relating to the establishing of a panel, and may well be satisfied in a particular case by listing the Articles allegedly violated. ${ }^{9}$

\subsection{Turkey's Claims Concerning Failures in Morocco's Dumping Investigation}

With regard to Turkey's claims concerning certain failures in the investigation carried out by Morocco in violation of Articles 5.10, 6.8, and 6.9 of the AD Agreement, the Panel found several violations.

First, the Panel found that Morocco had acted inconsistently with Article 5.10 of the ADA by failing to conclude the investigation within the 18-month maximum time limit set out in that provision. The Panel emphasized the phrase 'in no case' of Article 5.10 to conclude that the 18-month limit is a strict one and does not allow for any exception (for example, according to the Panel, requests from interested parties during the investigation proceedings do not justify a delay beyond 18 months in concluding the investigation). ${ }^{10}$

Second, the Panel also found that Morocco had violated Article 6.8 ADA by rejecting the producers' reported information and establishing the margins of dumping for the two investigated Turkish producers on the alternative basis of 'facts available' (thus using the petition rate of $11 \%)$. Morocco's reason for rejecting the entirety of producers' information was that the Moroccan authorities had found a discrepancy between the 18,800 tonnes of export sales to Morocco reported by the two investigated producers and the 29,000 tonnes of imports from

\footnotetext{
${ }^{6}$ Panel Report, Morocco-Hot-Rolled Steel (Turkey), paras. 7.43 and 7.58.

${ }^{7}$ Ibid., para. 7.24.

${ }^{8}$ Ibid., para. 7.24 .

${ }^{9}$ Ibid., para. 7.24 .

${ }^{10}$ Ibid., paras. $7.72,7.76$, and 7.78 .
} 
Turkey registered by Moroccan import statistics. The Panel accepted Turkey's claim under Article 6.8 as in its final determination, Morocco had failed to make an affirmative determination that the investigated producers had in fact failed to report particular export sales. The Moroccan authority had in fact stated that the explanations and evidence provided by the producers did not allow it to clearly establish whether or not the producers had reported the export sales at issue. ${ }^{11}$ In the view of the Panel, such failure was linked with the investigating authority's failure to engage meaningfully with the producers on this issue.

Third, the Panel found a violation of Article 6.9 ADA because Morocco had failed to inform all interested parties of any essential facts related to (i) the determination by the investigating authority that the two Turkish producers had failed to report certain 'additional, unidentified export sales' and (ii) the data and methodology used in the determination of the producers' margins of dumping (for example, the draft final determination did not provide any information on the cost and freight prices or the adjustments applied to them). The Panel, on the other hand, rejected one of Turkey's claims based on Article 6.9 ADA, concluding that five days is in fact 'sufficient time for the parties to defend their interests'.

\subsection{Turkey's Claims Concerning Morocco's Determination of Injury}

With regard to Turkey's claims based on Articles 3.1 and 3.4 ADA concerning the determination of injury, the Panel also found several violations. As Morocco had relied on the 'material retardation of the establishment of the domestic industry' as the relevant injury, Turkey had challenged the determination that (a) the relevant domestic industry in Morocco was 'unestablished' and (b) Turkish imports had 'materially retarded' that industry's establishment.

First, the Panel found that, in determining that the domestic industry was 'unestablished', Morocco had acted inconsistently with Article 3.1 ADA by failing to base its injury determination on 'positive evidence' and 'objective examination'. The Panel stressed first that "'positive evidence" refers to the facts underpinning and justifying the injury determination' and that 'the word "positive" means that the evidence must be of an affirmative, objective, and verifiable character, and it must be credible." The Panel also noted that 'the term "objective examination" requires an injury investigation to conform to the dictates of the basic principles of good faith and fundamental fairness' and that the relevant factors 'be investigated in an unbiased manner'. ${ }^{13}$ The investigating authority's determination that the relevant domestic industry was 'unestablished' was based on the following five criteria: (1) how long the domestic industry had been producing the domestic like product; (2) the market share of the domestic like product; (3) whether the domestic industry's production had been stable; (4) whether the domestic industry had reached profitability/break-even point; (5) whether the domestic industry constituted a 'new' industry. ${ }^{14}$ Based on a review of that determination, the Panel concluded that the investigating authority failed to assess whether the domestic industry was indeed established, based on positive evidence and an objective examination. The Panel noted several flaws in the authority's reasoning and findings in respect of all five criteria that formed part of its five-tiered test. ${ }^{15}$

With regard to the first criterion, the investigating authority found that the domestic industry (i.e., Maghreb Steel) had not been producing and selling hot-rolled steel longer than 30 months and thus concluded that that period was not sufficient for it to be considered an established industry. ${ }^{16}$ The investigating authority noted in that regard that in the case at hand, the starting up of production and the marketing of a product such as hot-rolled steel sheets requires a lead

\footnotetext{
${ }^{11}$ Ibid., para. 7.91 .

${ }^{12}$ Ibid., para. 7.154 .

${ }^{13}$ Ibid., para. 7.154 .

${ }^{14}$ Ibid., para. 7.141 .

${ }^{15}$ Ibid., para. 7.219 .

${ }^{16}$ Ibid., para. 7.157 .
} 
time of more than two years in view of the difficulty of mastering a heavy industry such as hot-rolling, as well as high-entry costs and the scale of the investment. The Panel, on the other hand, concluded that the investigating authority did not properly find that Maghreb Steel had produced hot-rolled steel for a period inadequate to consider it an established industry. In particular, the Panel highlighted the fact that, in its determination, the investigating authority had not adduced any positive evidence showing that the difficulties faced by Maghreb Steel necessarily reflect the norm in the hot-rolled steel industry. ${ }^{17}$

With regard to the third criterion, the Panel concluded that the investigating authority had not properly made the finding that Maghreb Steel had not met its break-even thresholds in each year of the injury period (2010-2012). The Panel noted that, by reaching its conclusion relying only on the data provided by Maghreb Steel for 2012, the investigating authority could not have objectively concluded that Maghreb had failed to meet its break-even threshold throughout the injury period. ${ }^{18}$

With regard to the last and fifth criterion, the Panel concluded that the investigating authority 'did not give a reasoned and adequate explanation' for its finding that Maghreb Steel was a 'new' and thus unestablished industry and not simply a case where an industry expands its activities by introducing a 'new product line' alongside old ones. ${ }^{19}$ In particular, the Panel found that the various elements relied on by the investigating authority to conclude that Maghreb Steel was indeed a 'new industry' were either not conclusive (such as the absence of competitors in the market), not convincing (such as the physical separation of production facilities of hot-rolled and cold-rolled steel, the size of the investment), or unsupported by evidence on the record (such as the different networks of clients and distribution). ${ }^{20}$

Finally, with regard to the investigating authority's determination that Turkish imports had 'materially retarded' the establishment of the relevant domestic industry, the Panel concluded that Morocco had acted inconsistently with Articles 3.1 and 3.4 ADA in (a) failing to evaluate five of the fifteen injury factors listed in Article $3.4,{ }^{21}$ (b) disregarding the captive market in its injury analysis, and (c) relying on the McLellan report (on which the Business Plan was based) without considering the significance of the inaccuracies in that report.

In particular, with regard to the failure to evaluate five of the injury factors in Article 3.4, the Panel emphasized the interpretation given by the Appellate Body according to which an investigating authority enjoys a margin of discretion in the manner in which that authority sets out the results of the 'evaluation' of each of the fifteen factors listed in Article 3.4 ADA in its published documents. Accordingly, an investigating authority is not required to make a separate record of the evaluation of each of the injury factors. However, a panel conducting an assessment of an antidumping measure needs to be able to find in the record 'sufficient and credible evidence' to satisfy itself that a factor has been evaluated, even though a separate record of the evaluation of that factor has not been made. After a detailed analysis, the Panel found that, at least with regard to five factors listed in Article 3.4 (relating to 'return on investments', actual and potential negative effects on cash flow, wages, growth, and ability to raise capital or investment), the investigating authority failed to evaluate them either directly or indirectly and thus acted inconsistently with Articles 3.1 and 3.4.

\section{Defining an 'Unestablished' or 'Nascent' Industry: A Missed Opportunity?}

One of the novel features in the present dispute revolves around the question of how to determine whether or not a domestic industry is established in the context of determining 'injury' due to the material retardation to the establishing of a domestic industry (in an anti-dumping investigation).

\footnotetext{
${ }^{17}$ Ibid., para. 7.165 .

${ }^{18}$ Ibid., para. 7.194 .

${ }^{19}$ Ibid., paras. 7.210-218.

${ }^{20}$ Ibid., para. 7.218 .

${ }^{21}$ Ibid., para. 7.237.
} 
While Article 3 of the ADA does provide for a non-exhaustive list of relevant factors for the determination of injury, it does not specify a definition of an 'established' or 'establishing' (i.e., nascent or unestablished) industry.

In Morocco Hot-Rolled Steel, the Panel may have missed an opportunity to explore and clarify how an investigating authority should define a nascent or unestablished industry for purposes of the lesser-used of the three forms of injury in an anti-dumping investigation under Article 3 ADA. While the Panel, as noted above, did conclude that the investigating authority had failed to assess whether the domestic industry was indeed 'established' based on positive evidence and an objective examination, it focused its analysis on the flaws of the investigating authority's reasoning, without examining whether the five criteria relied upon by the authority were correct.

In Section 4 below on 'The Economics of Antidumping in Support of Unestablished Industries', we will further develop the implications of such a missed opportunity. In the following subsections, we will briefly put forward two possible factors that may have contributed to the Panel's missing such an opportunity: first, the infamous issue of the panel's standard of review in antidumping disputes and, second, one of the Panel's early jurisdictional decisions (involving footnote 9 to Article 3).

\subsection{The Panel's Standard of Review in Antidumping Disputes: Deferential Review or No Review at All?}

A panel's standard of review under the ADA has been one of the most controversial issues in WTO law (and apparently one of the bones of contention advanced by the United States to justify its current blocking of any new appointment of Appellate Body members). This wider context may explain the Panel's reluctance to confront the question of the relevant definition of an 'established' industry for purposes of determining material retardation. As noted above, the Panel simply accepted the five criteria identified by the Moroccan investigating authority and limited its analysis to whether the authority had applied those criteria based on positive evidence and objective examination.

Interestingly, in its Article 3.1 ADA review of the investigating authority's finding that the domestic industry was unestablished, the Panel noted that 'an investigating authority enjoys a certain degree of discretion in adopting a methodology to guide its analysis'. ${ }^{22}$ However, the Panel also noted that the exercise of this discretion needs to comply with the requirements of Article 3.1 (that is any determination must be grounded in 'positive evidence' and involve an 'objective examination'). In particular, the Panel stressed that 'when an investigating authority's determination rests upon assumptions, these assumptions should be derived as reasonable inferences from a credible basis of facts, and should be sufficiently explained so that their objectivity and credibility can be verified'. ${ }^{23}$

While an investigating authority's relevant 'methodology' would appear to include the relevant criteria chosen to determine whether or not the relevant industry is established, the Panel seems to hone in only on the application of the criteria chosen by the Moroccan authority, rather than the criteria themselves. Now, Article 17.6(ii) ADA does appear to grant more deference to the investigating authorities by allowing their conclusions to rest on 'permissible interpretations' of the ADA, even if the WTO adjudicating bodies would have reached a different conclusion. However, the Panel in this case did not even address whether the interpretation of the relevant concept ('unestablished' industry) in Article 3 ADA was indeed among the interpretations permitted by Article 17.6(ii). In other words, more than granting deference, the Panel appears to have avoided the issue altogether.

\footnotetext{
${ }^{22}$ Ibid., para. 7.155 .

${ }^{23}$ Ibid., para. 7.155 .
} 
An alternative explanation of the Panel's apparently timid approach may more simply rest in the Panel's preference for a more procedural review of an investigating authority's findings, which relies on the strength of the evidence and the quality of the reasoning. This seems to be, in the view of the Panel, a key feature of a review under Article 3.1 ADA. As noted above, the Panel stressed several times the reference to 'positive evidence' and 'objective examination' in Article 3.1 ADA.

\subsection{Jurisdictional Decision: Article 3.1 is 'In' but Footnote 9 to Article 3 is 'Out'}

The Panel's jurisdictional decision with regard to Article 3 ADA may be a second factor that has influenced the Panel's decision to avoid addressing head-on the question of the proper definition of an 'unestablished' industry.

As noted above, while the Panel rejected Morocco's jurisdictional objection with regard to Turkey's claims under Articles 3.1 and 3.4 ADA based on the alleged failure by Turkey, in its request for consultations, to provide an 'indication of the legal basis' of the claims under Articles 3.1 and 3.4 in respect to certain findings concerning injury, the Panel did accept Morocco's objection with regard to Turkey's claims based on footnote 9 to Article 3 because, in its panel request, Turkey had failed to present the problem clearly.

It should be remembered that, while Article 3.1 specifies that a determination of injury be based on 'positive evidence' and involve an 'objective examination' of the volume and effect of dumped imports (as well as the impact of such imports on the relevant domestic industry), footnote 9 provides a definition of 'injury' that includes the 'material retardation of the establishment' of a domestic industry, which was at issue in the present dispute.

The Panel's jurisdictional decision may appear at first sight inconsequential. In its written submission, Turkey had advanced a claim concerning the investigating authority's finding that the domestic industry was 'unestablished' under both Article 3.1 and footnote 9 to Article 3 ADA. However, because Turkey's panel request had only referred to Articles 3.1 and 3.4 ADA and Article VI:6(a) GATT, not footnote 9, the Panel concluded that a claim based on footnote 9 was outside its terms of reference. The Panel, however, did not deny the 'definitional' relevance of footnote 9 for purposes of the parallel claim based on Article 3.1: 'Turkey is correct in pointing out that the 'determination of injury must be made in accordance with the definition of "injury" provided in footnote 9.' In other words, despite the jurisdictional decision, the key issue of when an industry should be considered 'established' or 'unestablished' for purposes of an injury determination under Article 3 ADA was clearly before the Panel.

However, it may be that this initial jurisdictional decision (separating the claim under Article 3.1 from the claim under footnote 9) may have led the Panel, in its subsequent examination of the investigating authority's injury determination, to focus on the latter more procedural failings with regard to the evidence and reasoning underlying its findings, rather than on the broader substantive issue of what constitutes an 'unestablished' industry.

\section{The Economics of Antidumping in Support of Unestablished Industries}

The Morocco-Turkey Hot-Rolled Steel case raises some important questions about the optimal way to design a trade agreement to support development of new industries. The unique feature of Morocco-Turkey was that Morocco tried to use antidumping policy to support the 'establishment of a new industry' in a situation in which it claimed price-undercutting was materially retarding the industry's development.

This case highlights a big picture question for economists: what types of policies should the WTO agreements permit to support establishment of a new domestic industry? Does it make sense to allow the use of antidumping duties to prevent the 'material retardation of the 
establishment of ... an industry ${ }^{24}$ or could the same goal be achieved by requiring that all countries use safeguard measures for infant industry protection? What role could domestic subsidies play in establishing new industries? A challenge for an activist government that wants to subsidize domestic production is that the Agreement on Subsidies and Countervailing Measures could inhibit a subsidized industry's future plans to export. ${ }^{25}$

In our legal analysis of the case, we explained that the investigation conducted by the MDCCE was found by the Panel to have fallen short on a number of specific procedural points, ultimately resulting in a win for Turkey on the substantive point that the antidumping duties were inconsistent with WTO rules. On economic grounds, the case raises questions about the precise economic criteria introduced in MDCCE's analysis of whether Mahgreb Steel was an established industry. Notably, these five criteria do not consider the relationship between an 'industry' and the 'like product' that is the subject of the antidumping investigation. Further, the selected criteria did not address how to treat integrated production and within-firm cross-subsidization of product lines. If an argument can be made to support the use of antidumping policy to prevent material retardation of a new industry, what objective economic criteria should an investigating authority apply? The economic analysis will consider if the five test criteria are individually sufficient to make an objective assessment, if two or more criteria are better examined jointly or holistically, and if there are relevant factors that the five criteria exclude or omit.

In reviewing these criteria, we will also point out when the case touched upon substantive and difficult questions for economics including: can a single firm constitute a domestic industry and, if yes, should the same economic criteria used in evaluating the establishment of a multi-firm domestic industry be applied to a domestic monopolist? What is the boundary of an industry? Does an industry encompass products related in an upstream-downstream integrated production chain? How should a firm's product scope inform the quantitative analysis of whether or not an industry is 'established'?

Finally, we will turn to a general examination of policy tools for protecting infant industries and facilitating industrial revival or change.

\subsection{What Is an Established Industry?}

Morocco's conclusion that Mahgreb Steel should be protected by antidumping duties was based, in large part, on its finding that Mahgreb's hot-rolled steel unit was not an 'established industry'. The Moroccan argument that Mahgreb Steel's hot-rolled steel was not an 'established industry' was based on five criteria: (1) duration of production, (2) the domestic market share of the like product, (3) whether production had been stable, (4) whether the domestic industry had reached a 'breakeven' point, and (5) whether the domestic industry was 'new'. ${ }^{26}$ On the legal side, the Panel found fault with how Mahgreb Steel applied some of these criteria. In the absence of explicit criteria in the Agreement on Antidumping for determining if an industry is established, our economic analysis reviews the utility of Morocco's chosen criteria.

Before turning to the five criteria, it is useful to summarize key features of the economic environment in the case that came before the Panel. The nature and degree of competition and the market structure for hot-rolled steel in Morocco should shape how we view various statistics.

1. A single domestic firm, Mahgreb Steel, competed in the domestic Moroccan market against two Turkish producers. Turkish steel was also sold in Morocco via middlemen. This

\footnotetext{
${ }^{24}$ Footnote 9 of Article 3 Agreement on Antidumping.

${ }^{25}$ Governments around the world are increasingly looking more favorably toward state aid and subsidies, but the WTO places strong disciplines on their use in exports. The uneasy balance that GATT 1994 struck between national sovereignty and international rules is reflected in the increasingly tense debates over state support for domestic industries between the US and China, the EU and UK, and Japan and Korea.

${ }^{26}$ Panel Report, Morocco-Hot-Rolled Steel (Turkey), para. 7.141.
} 
suggests that hot-rolled steel competition was largely oligopolistic, but disciplined by a competitive fringe. Alternatively, the market might be best described as monopolistically competitive.

2. The fixed costs of building a hot-rolled steel plant are substantial. The parties debated whether the time and financial costs associated with building Mahgreb's Bleb Solb complex, for which construction began in 2007, but production did not commence until 2010, was typical or unique and due to Mahgreb's mis-management. Regardless, it seems clear that hot-rolled steel production uses an increasing returns to scale technology. This implies that average production costs, which include both fixed and variable costs, tend to decline over time. Equivalently, this implies that in a long-run equilibrium, positive price-cost margins (or positive operating profits) are necessary to recoup the initial investment.

3. Mahgreb Steel was a multiproduct firm. It produced steel tubing, cold-rolled steel products, and hot-rolled steel products. These products were sold directly to arm's length customers.

4. Mahgreb Steel was a vertically integrated producer; a substantial proportion of Mahgreb's hot-rolled output was used as an input into other Mahgreb products.

With these facts in mind, we turn to evaluating the five criteria.

\section{(1) The Duration of Operations and Introduction of 'New' Products}

One question at issue was whether the absence of production data for at least 36 months for a specific set of products automatically implied that the hot-rolled steel industry was not established. Empirical studies of firm and product dynamics can offer some guidance regarding these criteria by placing the statistics from the Mahgreb case in context.

The empirical literature in economics regarding firm lifespans suggests that using a bright line cutoff of at least 36 months of production was highly arbitrary. By way of comparison, an exhaustive study of the survival of publicly listed US firms over 1950-2009 found half-lives of between 7 and 12 years (Daepp et al., 2015). If we define 'established' firms as those that can publicly list their stock, statistics indicating that one-half of US-listed firms do not survive for seven years suggests that a firm producing for 30 months is well established.

Perhaps more directly relevant to Mahgreb Steel, which was founded in 1975 and introduced hot-rolled production over 2007-2010, Bernard et al. (2010) documented that one-half of all US manufacturing firms alter their mix of products every five years. Thus, in comparison to the universe of US manufacturing firms, decisions to add product lines, including ones that are temporarily or ultimately unprofitable, appears normal and routine and does not imply that a firm is 'unestablished'.

\section{(2) Market Share, the Stability of Production, and the Breakeven Point}

Morocco's Investigating Authority rejected the use of total market share as well as the share of the non-captive 'merchant market' as criteria for determining whether the industry was established. Further, the MDCCE emphasized below cost sales as indicating the industry was not stable and had not achieved a critical 'breakeven point' such that the (internal transfer) price of its hot-rolled steel was able to cover the cost of production. ${ }^{27}$ On the legal and procedural side, the Panel found that Morocco's rejection of market share was not objective. Further, Morocco failed to show that it had conducted a transparent and thorough analysis of the 'breakeven point' with deficiencies in how it assessed the internal transfer price of hot-rolled steel that was used as an input into other Mahgreb Steel products. More generally, our economic analysis raises questions about the

\footnotetext{
${ }^{27}$ The Panel found fault with the MDCCE's record on defining and explaining basic facts about the analysis of the breakeven threshold, citing 'it remains unclear what price the MDCCE assigned to transfers of hot-rolled steel ...' (Panel Report, Morocco-Hot-Rolled Steel (Turkey), para. 7.184).
} 
suitability of using the 'breakeven threshold' as a major criterion for determining a firm or industry as established.

For illustrative purposes, we can briefly consider three distinct market structures in which firms have relatively high fixed costs of production. A domestic monopolist, a Cournot oligopoly with a small number of firms, and a monopolistically competitive market with a large number of firms.

(i) Domestic monopolist. When the size of a domestic market is relatively small and the cost of establishing production is high (due to costly machinery and capital requirements, for example), it is possible that, in equilibrium, only a single firm can profitably serve a market (see Bresnahan and Reiss, 1991, among others). The domestic market size determines the viability of entry; if the market is too small, it is possible that a single entrant might never produce sufficient output to recover the costs of building a plant. Thus, one would only expect to observe entry when the market is sufficiently large that the firm can reasonably expect that future sales will cover its start-up costs.

In an economy that is open to trade, price fluctuations (driven by global cycles) imply that a viable or established firm will experience losses in some years, profits in others. The global fluctuations can also induce sharp fluctuations in output. Thus, evidence that a firm cannot recover a price above its long-run average costs over a narrow time window would be insufficient to show a firm is unestablished. However, examining the firm's price relative to costs over a reasonably long time frame in conjunction with information on the firm's total domestic market share would be a valuable exercise. A small market share observed alongside a small, zero, or negative price cost margin over multiple years would be good evidence that a firm is not established (or viable).

(ii) Cournot oligopoly. A natural extension of the monopoly case described above is the multi-firm oligopoly. Theoretical and empirical research (Bresnahan and Reiss, 1991; Campbell and Hopenhayn, 2005) has shown that the market size will determine how many firms can be profitably sustained in the presence of fixed entry costs. In some cases (large market demand, modest entry costs), many firms can be supported. In others (small market demand, high entry costs), only a single firm might be able to profitably supply a market. A key finding of this framework is that fixed costs discourage excessive entry, leading to sizeable price-cost markups that decline as market size increases and more firms enter. In a market of this type, operating firms have some power to set high(er) prices. The corollary is that welfare is enhanced by the entry of additional firms which reduce the profitability of the initial entrant(s). In the context of this type of competitive structure, evaluating the 'breakeven' price-cost markup of a domestic firm(s) would be a useful exercise to determine if an industry is 'established'. However, in this case, a small or zero price-cost markup and a modest market share would indicate a robust, competitive industry.

(iii) Monopolistic competition. In a market characterized by monopolistic competition, in which entering firms have different productivities, a firm's market share is correlated with its productivity and its price-cost margin (Melitz, 2003). In a long run equilibrium, the most productive firm would have the largest market share and highest price-cost markup. At the other end of the spectrum, the least productive firm would have very small to zero operating profits per unit. A monopolistically competitive industry is characterized by an empirical distribution of firms in which some firms operate profitably even though their gross profits never fully recoup their investment in capital or machinery.

In this framework, there is a tight link between a firm's market share and its price-cost margin so that either statistic in isolation would be informative about a firm's viability. However, the first step in an analysis of monopolistically competitive firms would be to evaluate the two statistics (market share and price-cost markup) jointly for all firms in the industry to determine if this framework correctly describes the industry. In a second step, any individual firm's market 
share could be evaluated with reference to its position in the distribution; the smallest market share firms would be most likely to be unviable. Finally, if a domestic industry's market share is comprised of a large number of firms, each of which has a very small market share and low or zero operating profits per unit, then one might conclude that the domestic industry is not viable.

In summary, a review of different competitive structures suggests that market share is a useful statistic for evaluating whether a firm or industry is viable, but it is generally more informative when examined in conjunction with price-cost margins. This holds regardless of whether the industry is a monopoly, an oligopoly, or monopolistically competitive.

\section{(3) Integrated Production and the Boundaries of an Industry}

The Moroccan Investigating Authority's criteria omitted any reference to important features of Mahgreb Steel. Firstly, Mahgreb was a multiproduct firm operating in several product lines. As there were undoubtedly some cost components, such as marketing or distribution, that were spread across all product lines, it seems mis-guided to have ignored this feature of the firm in the analysis of whether a particular product line was established. ${ }^{28}$

Secondly, Mahgreb used hot-rolled steel as an input into its other products. With a vertically integrated production structure, an input product should not be examined without some reference to its contribution to the profitability of other outputs. The double-marginalization problem for vertically related industries implies that integrated production of upstream and downstream products within a firm yields higher profits than would be earned by independently operating upstream and downstream producers. ${ }^{29}$ This implies that data on the profitability of other products should have been considered by the MDCCE.

\subsection{WTO Policy Instruments to Support Infant and Reviving Industries}

Three distinct WTO agreements, the Agreement on Subsidies and Countervailing Measures (ASM), the Agreement on Safeguards (ASG), and the Agreement on Antidumping (ADA), could in theory be used to support the development of an infant or reviving industry. In practice, there are limits to using each of these policies for this purpose. One could argue that the constraints on the use of these policies is necessary to promote fair competition among WTO members. However, recent efforts by governments to skirt the WTO rules or stretch them to support industrial development suggest that not all WTO members are satisfied with the current mix of policy instruments and the level of unilateral discretion permitted under the WTO Agreements.

Because infant and high-tech industries often receive financial support from governments, the WTO dispute settlement body has previously ruled in many countervailing duties cases involving the export of goods in a newly establishing industry. Most typically, but not always, these cases find evidence that subsidization of exported merchandise caused injury to a domestic importcompeting industry and resulted in a ruling that disciplines or constrains the offending policy. ${ }^{30}$ Thus, the ASM has an inherent pro-'fair competition'/anti-government intervention bias. At the same time, the ASM has limited applicability - it only applies to cases in which an exporting country's subsidy harms import-competing firms; it is silent on the opposite situation in which subsidization of domestic production crowds out sales by foreign exporters. This highlights

\footnotetext{
${ }^{28}$ The allocation of costs within a multi-product is an empirically difficult task made harder by the fact that many alternative cost allocations can be justified for an efficient, profit-maximizing firm. See Alcover and Crowley (2020) for a discussion of cost allocation in a dumping case involving a multi-product firm.

${ }^{29}$ See, for example, Belleflamme and Peitz (2015, pp. 452-487).

${ }^{30}$ Examples of WTO disputes over government support to a newly developing export industry include the Japan-Korea dispute over Korea's alleged support for Hynix, a computer chip manufacturer (Crowley and Palmeter, 2009) and EU-Argentina dispute over Argentina's export tax on soyabeans which had a subsidy-like effect on the Argentine biodiesel industry (Crowley and Hillman, 2018).
} 
the nature of the ASM as a less-than-comprehensive agreement over subsidies - it is only pro-'fair competition' half of the time.

Historically, safeguard measures have been used to protect domestic import-competing infant industries and facilitate industry revival. The theoretical literature in economics that has explored the efficacy of infant industry tariffs (Matsuyama, 1990; Miyagiwa and Ohno, 1995, 1999, Crowley, 2006; Maggi and Rodriguez-Clare, 2007) has generally found that a tariff or trade policy with features similar to safeguards (in duration, exogeneity of the timing of application/removal, breadth of protection, etc.) are more efficacious in achieving long-term policy goals (technological improvement, efficient allocation of resources, etc.) than tariff policies with features that match antidumping (duration of protection conditional on choices of domestic firms, breadth of protection, etc.) Altogether, this indicates that the $\mathrm{AB}$ ruling in Argentina-Footwear, ${ }^{31}$ which effectively raised the threshold for injury determinations in safeguards cases by strengthening the 'unforeseen developments' clause has effectively closed off useful policy space.

The case of Morocco-Hot-Rolled Steel (Turkey) demonstrates that a government with a legitimate (albeit protectionist) policy goal of protecting a newly developing industry has limited policy options. In this case, with little prospect that a safeguards case could withstand a WTO challenge, Morocco was forced into an extensive charade of trying to prove dumping and injury in a situation in which predatory price-undercutting was not taking place. This case highlights that antidumping policy, which is widely seen as the policy tool over which imposing governments have the greatest unilateral discretion and the easiest-to-satisfy injury test, enjoys a continually expanding role as the go-to policy whenever a country desires to protect a domestic industry.

\section{Conclusions}

We have argued that this case introduces a new facet of antidumping policy into WTO practice. In its efforts to use antidumping duties on hot-rolled steel, Morocco tried to establish antidumping's use as a policy tool for protecting unestablished industries. Our legal and economic analyses have shown that the Panel's report, which focused on procedural claims and evaluating whether the investigation was based on objective examination and positive evidence, may have missed an opportunity to define an 'unestablished industry'. Cases like this one will almost certainly come forward in the future; at present there is no clear guidance for how an investigating authority should determine whether an industry is established. We have offered a first assessment of the criteria considered by Morocco and have suggested additional criteria that would be relevant to an objective evaluation.

In this case, Morocco showed itself to be ahead of the curve in offering policy support to a firm that was trying to 'onshore' components that fed into its domestic steel supply chain. We observe a government using an antidumping policy to support a firm trying to develop the in-house capability to produce inputs necessary to its production. The last few years, featuring Trump's America First trade policies and a worldwide scramble by governments to re-shore production of medical equipment and supplies needed to fight Covid-19, have shown that (1) reshoring is difficult and costly and (2) there seems to be little policy space to pursue reshoring (for legitimate reasons) while remaining within WTO rules.

\section{References}

Alcover, M. and M. Crowley (2020) 'China-Broiler Products (Article 21.5 - United States) - can the sum of the parts be less than the whole?', World Trade Review 19, 282-296.

\footnotetext{
${ }^{31}$ See Appellate Body Report, Argentina - Safeguard Measures on Imports of Footwear, WT/DS121/AB/R (14 December 1999).
} 
Belleflamme, P. and M. Peitz (2015) Industrial Organization: Markets and Strategies, 2nd edn. Cambridge: Cambridge University Press.

Bernard, A.B., S.J. Redding, and P.K. Schott (2010) 'Multiple-Product Firms and Product Switching', American Economic Review 100(1), 70-97.

Bresnahan, T. and P. Reiss (1991) 'Entry and Competition in Concentrated Markets', Journal of Political Economy 99(5), 9771009.

Campbell, J. and H. Hopenhayn (2005) 'Market Size Matters', The Journal of Industrial Economics 53(1), 1-25.

Crowley, M. (2006) 'Do Safeguard Tariffs and Antidumping Duties Open or Close Technology Gaps?', Journal of International Economics 68, 469-484.

Crowley, M. and J. Hillman (2018) 'Slamming the Door on Trade Policy Discretion? The WTO Appellate Body's Ruling on Market Distortions and Production Costs in EU-Biodiesel (Argentina)', World Trade Review 17(2), $195-213$.

Crowley, M.A. and D. Palmeter (2009) 'Japan - Countervailing Duties on Dynamic Random Access Memories from Korea (DS 336 and Corr. 1, adopted 17 December 2007)', World Trade Review 8, 259-272.

Daepp, M.I.G., M.J. Hamilton, G.B. West, and L.M.A. Bettencourt (2015) 'The Mortality of Companies', Journal of the Royal Society Interface 12, 20150120.

Maggi, G. and A. Rodriguez-Clare (2007) 'A Political-Economy Theory of Trade Agreements', The American Economic Review 97(4), 1374-1406.

Matsuyama, K. (1990) 'Perfect Equilibria in a Trade Liberalization Game', American Economic Review 80, 480-492.

Melitz, M. (2003) 'The Impact of Trade on Intra-Industry Reallocations and Aggregate Industry Productivity', Econometrica 71(6), 1695-1725.

Miyagiwa, K. and Y. Ohno (1995) 'Closing the Technology Gap under Protection', American Economic Review 85, 755-770.

Miyagiwa, K. and Y. Ohno (1999) 'Credibility of Protection and Incentives to Innovate', International Economic Review 40, 143-163.

Cite this article: Crowley MA, Ortino F (2021). Establishing a New Role for Antidumping Policy: Protection of an Unestablished Industry (Morocco-Hot-Rolled Steel (Turkey)). World Trade Review 20, 533-545. https://doi.org/10.1017/ S1474745621000082 